\title{
Russian Oil and Gas Challenges
}

\author{
Robert Pirog *
}

\section{Introduction}

The Russian Federation is a major player in world energy markets. It has more proven natural gas reserves than any other country, and is among the top ten countries in proven oil reserves. ${ }^{1}$ It is the world's largest exporter of natural gas, the second-largest oil producer and exporter, and the third-largest energy consumer. Given that the United States also is a major energy producer and user, Russian energy trends and policies affect U.S. energy markets, and U.S. economic welfare in general. ${ }^{2}$

\section{Oil and Gas Reserves and Production}

Most of Russia's 60-74 billion barrels of proven oil reserves (Table 1) are located in Western Siberia, between the Ural Mountains and the Central Siberian Plateau. The ample endowment of this region made the Soviet Union a major world oil producer in the 1980s, reaching production of 12.5 million barrels per day (bbl/d) in $1988 .{ }^{3}$ However, roughly 25 percent of Russia's oil reserves and 6 percent of its gas reserves are on Sakhalin Island in the far eastern region of the country, just north of Japan.

Russian oil production - which had begun to decline before the Soviet Union dissolved in 1991 — fell more steeply afterward, to less than six million bbl/d in 1997 and 1998. ${ }^{4}$ State-mandated production surges had accelerated the depletion of the large Western Siberian fields, and the Soviet central-planning system collapsed. Russian oil output started to recover in 1999. Many analysts attribute this to privatization of the industry, which clarified incentives and shifted activity to less expensive production methods. Increases in world oil prices, application of technology that was standard practice in the West, and rejuvenation of old oil fields helped boost output. The aftereffects of the 1998 financial crisis and the subsequent devaluation of the ruble may

* Robert Pirog is a Specialist in Energy Economics and Policy Resources in the Science, and Industry Division of the Congressional Research Service. This essay was prepared as a CRS Report for Congress, Order Code RL33212. The original version of this report was written by Bernard A. Gelb.

1 Oil and Gas Journal (19 December 2005). Estimates of proven oil and/or gas reserves by country can differ widely, depending partly on what types of resources are included. Thus, Russia's ranking of reserve holdings may differ among organizations that compile such data.

2 For broader coverage of Russian political and economic issues, see Stuart D. Goldman, Russian Political, Economic, and Security Issues and U.S. Interests, CRS Report RL33407 (Washington, D.C.: Congressional Research Service, updated 31 May 2007).

3 British Petroleum (BP), BP Statistical Review of World Energy, June 1992. Data for Russia only are not available for 1988.

4 British Petroleum, BP Statistical Review of World Energy 1997, June 1997. 


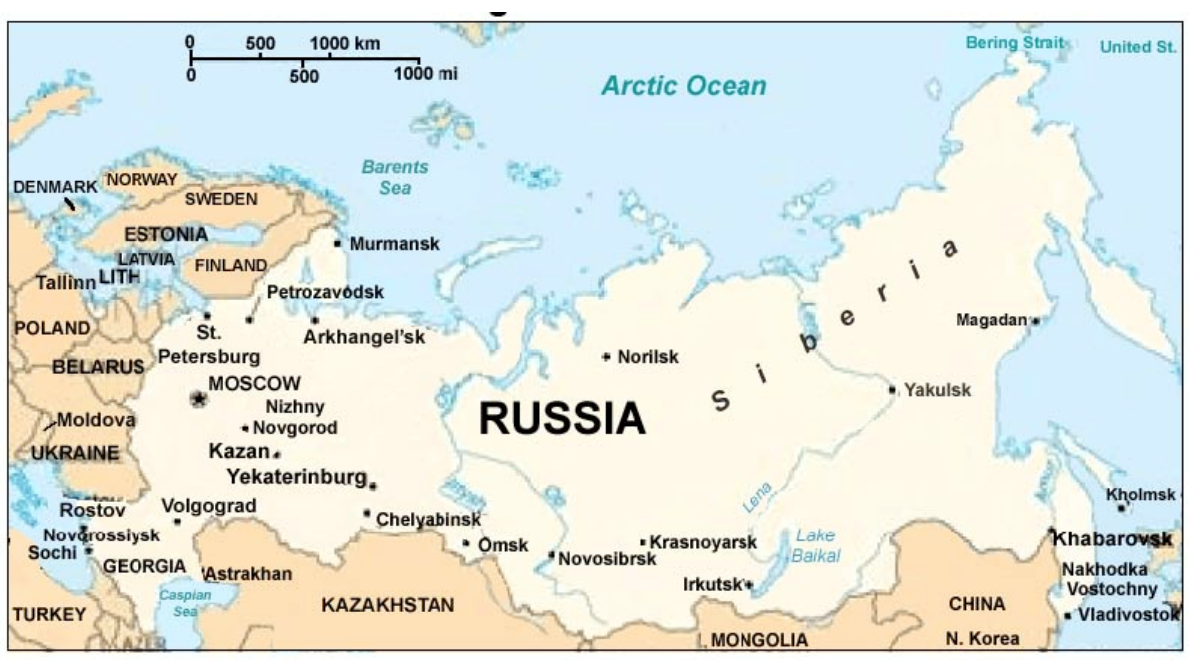

Figure 1: Russia ${ }^{5}$

well have contributed in this regard. Russian crude oil production reached 9.0 million bbl/d in 2005 and rose slowly in 2006 to 9.2 million bbl/d. ${ }^{6}$

However, Russian crude oil production has been exceeding growth in reserves, as "intensive deposit exploitation" combined with the continued reliance on old technology is leaving 65 percent of the oil in the ground, according to the director of the Russian Natural Resources Ministry. Between 1994 and 2005, the increase in Russian oil extraction was about eight billion barrels greater than the increase in reserves. Reserves in Western Siberia, Russia's prime oil producing region, fell by almost 23 billion barrels between 1993 and $2005 .{ }^{7}$

With about 1,700 trillion cubic feet (tcf), Russia has the world's largest reserves of natural gas. In 2005, it was the world's largest natural gas producer and the world's largest exporter. However, production by its natural gas industry has increased very little in recent years, and is projected to continue to increase slowly. ${ }^{8}$ Exports have only recently re-attained their level of the late 1990s.

The growth of Russia's natural gas sector has been impaired by aging fields, near monopolistic domination over the industry by Gazprom (with substantial government holdings), state regulation, and insufficient export pipelines. Gazprom, Russia's 51

5 Energy Information Administration, Russia Country Analysis Brief, February 2005; available at www.eia.doe.gov/emeu/cabs/Region_ni.html (viewed 3 December 2005).

6 Energy Information Administration (EIA), Country Analysis Briefs, Russia, April 2007; available at www.eia.doe.gov/emeu/cabs/Russia/Oil.html (viewed 8 January 2007).

7 “Russian Companies Face Crude Crunch,” FSU Oil \& Gas Monitor (18 April 2007), 12.

8 EIA, Country Analysis Briefs, Russia, April 2007; available at www.eia.doe.gov/emeu/cabs/ Russia/Natural Gas.html (viewed 15 May 2007). 
percent state-owned natural gas monopoly, holds more than one-fourth of the world's natural gas reserves, produces nearly 90 percent of Russia's natural gas, and operates the country's natural gas pipeline network. The company's tax payments account for around 25 percent of Russian federal tax revenues. Gazprom is heavily regulated, however. By law, it must supply the natural gas used to heat and power Russia's domestic market at government-regulated, below-market prices.

Table 1: Oil and Natural Gas ${ }^{a}$ Reserves and Production ${ }^{9}$

\begin{tabular}{|c|c|c|c|c|}
\hline \multirow{2}{*}{\multicolumn{2}{|c|}{$\begin{array}{l}\text { Country or } \\
\text { Region }\end{array}$}} & \multicolumn{2}{|c|}{$\begin{array}{l}\text { Proved Reserves } \\
\text { (billion bbls of oil/ } \\
\text { trillion cu. ft. of gas) }\end{array}$} & \multirow{2}{*}{$\begin{array}{c}\begin{array}{c}\text { Production } \\
\text { (mil. bbls/day of oil// } \\
\text { trillion cu. ft. of gas) }\end{array} \\
\text { BP } \\
(2005)\end{array}$} \\
\hline & & $\begin{array}{c}\text { BP } \\
\text { (End of 2005) }\end{array}$ & $\begin{array}{c}\text { O \& G Journal } \\
(1 / 1 / 07)\end{array}$ & \\
\hline \multicolumn{2}{|c|}{$\begin{array}{l}\text { Russian } \\
\text { Federation }\end{array}$} & $74 / 1,688$ & $60 / 1,680$ & $9.6 / 21.1$ \\
\hline \multirow{4}{*}{ 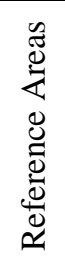 } & $\begin{array}{l}\text { United } \\
\text { States }\end{array}$ & 29/193 & $22 / 204$ & 6.8/18.9 \\
\hline & North Sea $^{b}$ & n.a./n.a. & $13 / 161$ & $5.9^{c} /$ n.a. \\
\hline & $\begin{array}{l}\text { Saudi } \\
\text { Arabia }\end{array}$ & $264 / 244$ & $260 / 240$ & $11.0 / 2.5$ \\
\hline & WORLD & $1,200 / 6,348$ & $1,317 / 6,183$ & $80.0 / 97.5$ \\
\hline
\end{tabular}

n.a. - not available.

a. Includes natural gas liquids.

b. Includes Denmark, Germany, Netherlands, Norway, and United Kingdom.

c. Energy Information Administration estimate.

Potential growth of both oil and natural gas production in Russia is limited by the failure to fully introduce the most modern Western exploration, development, and production technologies. Also, oil companies, whose natural gas is largely flared, and independent gas companies will play an important role by increasing their share of Russian total gas production from 9 percent in 2005 to around 17 percent by 2010, according to the Energy Information Administration. ${ }^{10}$ Their success, however, depends largely on gaining access to Gazprom's transportation network.

However, while the investment climate in Russia had been considered to be improving, there are reasons to argue that it is now worsening. As will be discussed below, a reported proposal to tighten restrictions on the extent to which foreign compa-

9 Information drawn from BP Statistical Review of World Energy, June 2006; Energy Information Administration, Country Analysis Briefs: North Sea, "Oil," August 2005 (available at www.eia.doe.gov/emeu/cabs/North_Sea/Oil.html); Oil \& Gas Journal (18 December 2006).

10 EIA, Country Analysis Briefs, Russia, April 2007. 
nies can participate in Russian oil and natural gas production would seem to discourage investment. An unsettled judicial system provides limited and uncertain protection of property rights and the rights of minority shareholders. Also, investors complain that the investment climate is inhospitable, citing factors such as burdensome tax laws and inefficient government bureaucracy.

\section{Exports}

Energy exports have been a major driver of Russia's economic growth over the last five years, as Russian oil production has risen significantly and world oil and gas prices have been relatively high. This type of growth has made the Russian economy highly dependent on oil and natural gas exports, and vulnerable to fluctuations in world oil prices. Based upon an International Monetary Fund study, a USD 1 per barrel increase in the price of Urals blend crude oil for a year results in a USD 3 billion increase in Russia's nominal gross domestic product. ${ }^{11}$

\section{Petroleum}

Almost three-fourths of Russian crude oil production is exported; the rest is refined in Russia, with some refined products then being exported. Of Russia's 6.7 million bbl/d of crude oil exports in 2004, two-thirds went to Belarus, Ukraine, Germany, Poland, and other destinations in Central and Eastern Europe. The remaining portion went to maritime ports and was sold in world markets. Recent high oil prices have enabled as much as 40 percent of Russia's oil exports to be shipped via railroad and river barge routes, which are more costly modes of transport than pipelines. Most of Russia's exports of refined petroleum products to Europe are distillate oil used for heating and by trucks.

Russia's capacity to export oil faces difficulties, however. One stems from the fact that crude oil exports via pipeline are under the exclusive jurisdiction of Russia's stateowned pipeline monopoly, Transneft. Bottlenecks in the Transneft system prevent its export capacity from meeting oil producers' export ambitions. Only about four million $\mathrm{bbl} / \mathrm{d}$ can be transported in Transneft's major trunk pipelines; the rest is shipped by rail and river routes. Most of what is transported via alternative transport modes is refined petroleum. The rail and river routes could become less economically viable if oil prices fall sufficiently. The Russian government and Transneft are striving to improve the export infrastructure.

Unless significant investments are made in improving the Russian oil pipeline system, the level of non-pipeline transported exports probably will grow. For example, rail routes presently are the only way to transport Russian crude oil to East Asia. Russia is exporting about 200,000 bbl/d via rail to the cities of Harbin and Daqing in

11 Antonio Spilimbergo, Measuring the Performance of Fiscal Policy in Russia, IMF Working Paper WP/05/241 (Washington, D.C.: International Monetary Fund, December 2005), 7. CRS has applied the IMF sensitivity factor to Russia's GDP for 2005 at the official exchange rate, USD 740.7 billion, as given in the Central Intelligence Agency's World Fact Book, available at https://www.cia.gov/cia/publications/factbook/geos/rs.html\#Econ. 
northeast China, and to central China via Mongolia. Since Yukos was the leading Russian exporter of oil to China, there was concern that the breakup of Yukos by the Russian government (see below, under "Energy Policy”) might affect rail exports to China. However, Lukoil now is the chief supplier of Russian oil to China.

U.S. markets could benefit from a proposed pipeline that would carry crude oil from Russia's West Siberian basin and Timan-Pechora basin westward to a deep-water tanker terminal at Murmansk on the Barents Sea. This could allow for between 1.6 and 2.4 million bbl/d of Russian oil exports to reach the United States via tankers within only nine days, much faster than shipping from the Middle East or Africa. Liquefied natural gas (LNG) facilities at Murmansk and Arkhangelsk (to the southeast) have also been suggested, possibly allowing for gas exports to American markets.

Oil transportation in the Black Sea region is in flux. A significant portion of Russia's oil is shipped by tankers from the Black Sea to the Mediterranean and to Asia, much of it from the port of Novorossiysk. However, transit through the shallow and congested Bosporus Straits is limited by Turkey for environmental and safety reasons, limiting the effective capacity of pipelines that terminate in Novorossiysk. ${ }^{12}$ Oil shipped through the Baku-Tbilisi-Ceyhan (BTC) pipeline is from Azerbaijan (and potentially from Kazakhstan as well), posing competition to Russian oil. ${ }^{13}$ Oil production in Azerbaijan has risen steeply in 2007 and, with ample BTC capacity, the Azerbaijan International Operating Company consortium has stopped using the Baku-Novorossiysk pipeline. ${ }^{14}$

To the east, Russia faces competition for China's oil market from Kazakhstan, which, in cooperation with China, completed in late 2005 the construction of a pipeline from Atasu in central Kazakhstan to Alaskankou on China's western border. Eventual capacity will be 190,000 bbl/d. ${ }^{15}$ Several consortia have also begun producing and exporting oil (mainly to East Asia at present) from Sakhalin island (Figure 4). They also plan to export gas to the United States via pipelines to the Siberian mainland and then from LNG terminals.

12 See, for example, Yigal Schleifer, "Russian Oil Ships Stuck in Bosporus Strait Traffic Jam,” Christian Science Monitor (25 January 2005). Limited depth, heavy traffic, and environmental considerations have resulted in restrictions by Turkish authorities on travel through the Bosporus. The Baku-to-Ceyhan pipeline has an advantage in that Ceyhan, a Turkish port on the Mediterranean, can handle very large carriers, while the ports of Novorossiysk and Supsa (in Georgia) are restricted to smaller tankers that can transit the Bosporus straits. Ceyhan can also remain open all year, whereas Novorossiysk is closed up to two months.

13

Kazakhstan and Azerbaijan have agreed to allow Kazakh oil to flow through the BTC pipeline. See “Kazakhstan Inks BTC Deal,” The Oil Daily (19 June 2006), 7.

14 “AIOC: Oil Production Up, BTC Now Handling All Exports,” FSU Oil \& Gas Monitor (25 April 2007).

15 Martin Clark, “Beijing Triumphs with Inauguration of Kazakhstani Crude Pipe,” FSU Oil \& Gas Monitor (21 December 2005). 


\section{Natural Gas}

Historically, most of Russia's natural gas exports went to Eastern Europe and to customers in countries that were part of the Soviet Union. But, in the mid-1980s, Russia began trying to diversify its export options. Gazprom has continued to shift some of its exports to meet the rising demand of European Union countries, Turkey, Japan, and other Asian countries. For Gazprom to attain its long-term goal of increasing its European sales, it will have to boost production as well as secure more reliable export routes to the west.

Issues have arisen with the growth of Russia's gas sales to Europe. EU trade representatives have criticized Gazprom's abuse of its dominant market position and twotiered pricing system, which charged higher prices on exports than on domestic sales. Russia agreed to grant domestic independent natural gas producers access to Gazprom's pipelines, and, in response to calls for fair pricing, the Russian government doubled prices to Russian industrial consumers. But the new price level still is less than half of the prices charged at the German and Ukrainian borders. To correct this, the Russian government has decided to increase domestic gas prices gradually over the next few years, with the aim of more than doubling them by $2011 .^{16}$

As a major supplier of natural gas to European countries, and the dominant supplier to some, Russia has some ability to set prices. ${ }^{17}$ For example, as will be discussed below, Gazprom has threatened to cut off natural gas supplies to certain countries if they did not agree to pay higher prices, and has actually done so. As the only seller of Russia’s gas, Gazprom is Russia's largest earner of hard currency.

Russia's natural gas exports to Europe declined markedly in January 2006 as a result of severely cold weather in Russia that greatly increased Russian gas consumption, and also reduced oil exports somewhat. The cold conditions lasted through the month. $^{18}$

As with oil, Russia faces competition for Asian gas markets from Kazakhstan, which, in concert China, is studying the feasibility of building a gas pipeline from the former to the latter to complement the oil pipeline completed in $2005 .{ }^{19}$ Given the proximity of gas producers Turkmenistan and Uzbekistan to Kazakhstan, it is possible that their gas also would go to China via that route.

16 Ed Reed, “Russian Gas Prices to Rise,” FSU Oil \& Gas Monitor (6 December 2006), 2.

17 For detailed data on the extent of Europe's dependence on Russian natural gas, see Bernard A. Gelb, Russian Natural Gas: Regional Dependence, CRS Report RS22562 (Washington, D.C.: Congressional Research Service, 18 January 2007).

18 “Cold Spell Cuts Russian Gas to Europe,” Financial Times (18 January 2006), at www.FT.com; “Cold Weather Cutting Russian Gas Exports,” Oil \& Gas Journal Online (23 January 2006).

19 “Kazakhstan, China Consider Gas Pipeline Construction,” FSU Oil \& Gas Monitor (7 December 2005). 


\section{Energy Policy ${ }^{20}$}

The Russian government has moved to take control of the country's energy resources, and to try to use that control to exert its influence elsewhere. It is arguable that this push for control was partly the motivation behind the government's prosecution of Mikhail Khodorkovsky, the CEO of Yukos, who acquired state-owned assets during the period of privatization and adopted open and "transparent" business practices while transforming Yukos into a major global energy company. Yukos is being broken up, with its principal assets being sold off to meet alleged tax debts. Yuganskneftegaz, Yukos' main oil production subsidiary, was sold at a state-run auction to the Baikal Finans Group-a previously unknown entity, which was the sole bidder-for USD 9.4 billion (about half its market value, according to Western industry specialists). The Baikal group soon after sold the unit to Rosneft, the state-run oil company. ${ }^{21}$ Yukos' creditors voted to liquidate the company on 25 July 2006, and the Moscow arbitration court confirmed the vote. ${ }^{22}$ Portions of Yukos have been sold off piecemeal since then. Another government takeover followed when Gazprom bought 75 percent of Sibneft, Russia's fifth-largest oil company. ${ }^{23}$

A possible shift to a less aggressive policy stance was hinted at when President Putin announced on 31 January 2006 that Russia would not seek state control of any additional oil companies. ${ }^{24}$ However, the Duma voted to give Gazprom the exclusive right to export natural gas, and, as described below, Russia moved to limit participation by foreign companies in oil and gas production. ${ }^{25}$ In addition, Gazprom gained majority control of the Sakhalin energy projects.

In Eastern Europe, Russian firms with close links to the Russian government have used leverage to buy energy companies in order to gain a higher level of control over

20 Much of the material in this section is from Goldman, Russian Political, Economic, and Security Issues and U.S. Interests, and Emma Chanlett-Avery, Rising Energy Competition and Energy Security in Northeast Asia: Issues for U.S. Policy, CRS Report RL32466 (Washington, D.C: Congressional Research Service, 20 January 2006).

21 It was subsequently revealed that Baikal Finans consisted of a group of Kremlin insiders headed by Igor Sechin, Deputy Head of the Presidential Administration and a close associate of President Putin. Sechin has been Chairman of Rosneft's board of directors since July 2004. The de facto nationalization of Yuganskneftegaz was declared "the fraud of the year" by Andrei Illarionov, President Putin’s chief economic advisor; see Simon Romero and Erin E. Arvedlund, “U.S. Court to Hear Arguments for Dismissal of Yukos Case," New York Times (7 January 2005).

22 "Yukos: The Final Curtain,” FSU Oil \& Gas Monitor (26 July 2006), 5; Ben Aris, "Death of Yukos,” FSU Oil \& Gas Monitor (2 August 2006), 4.

23 "New Takeover to Make Russia’s Giant Gazprom one of the World's Largest Oil and Gas Companies," Pravda (1 October 2005); at english.pravda.ru/russia/economics/01-10-2005 /8997-gazprom-0 (viewed 6 February 2006).

24 “Putin: Private Oil Companies to Remain Private," FSU Oil \& Gas Monitor (1 February 2006).

25 Tobias Buck and Neil Buckley, "Russian Parliament Vote Backs Gazprom Export Monopoly,” Financial Times (16 June 2006), 8. 
energy supply. For example, Yukos obtained majority control over a Lithuanian refinery (the only one in the Baltic states) by slowing the oil supply to it, and then buying it at a reduced price. The Transneft pipeline monopoly diverted the flow of oil shipments to Primorsk, a Russian port, stopping flow to the Latvian port of Ventspils. Some see Transneft's action as a move to obtain control of the firm that operates the Ventspils terminal. ${ }^{26}$ Transneft also refused to finalize an agreement to transport Kazakh oil to Lithuania, undermining Kazakhstan's KazMunaiGaz's attempt to buy the refinery. After several developments, an agreement was reached for Yukos to sell the refinery to a Polish firm. ${ }^{27}$

Another example of Russia's efforts to maintain or increase control over regional energy supplies is the routing of new and planned export pipelines. For example, Russia has agreed with Germany, with the support of the United Kingdom, to supply Germany (and, eventually, the U.K.) directly by building a natural gas pipeline under the Baltic Sea, thus bypassing Ukraine and Poland. In late January 2006, Gazprom was negotiating with Uzbekistan to obtain control of three of that country's gas fields. ${ }^{28}$ Russia is also hoping to participate in the venture that is constructing a gas pipeline between Turkey and Greece. ${ }^{29}$

Several actions in recent years by Russia or its economic agents have been characterized by some as perhaps overaggressive. In 2005, Gazprom wanted to raise the price paid by Ukraine for gas to market levels (this price was originally a fraction of the world market price, a discount offered by Russia in return for Ukraine's transmission of Russian gas). ${ }^{30}$ When negotiations failed, Gazprom reduced gas pressure and flow through the Ukrainian network on 1 January 2006. Ukraine compensated by using some gas intended for sale in Western Europe. Gazprom restored supply very shortly after, when those European countries complained and pointed out that Russia was risking its reputation as a reliable energy supplier. ${ }^{31}$ The dispute was resolved temporarily on 4 January 2006 when Gazprom agreed to sell gas at its asking price to a trading company that would mix Russian gas with less expensive gas from Central Asia and sell the mixture to Ukraine at a higher price than Ukraine had indicated it was willing to pay, but one that was much lower than the price that Gazprom had initially sought to impose. Gazprom would pay cash instead of gas in kind to Ukraine’s pipeline

26 Ariel Cohen, “Don’t Punish Latvia,” Washington Times (5 May 2003).

27 “Poland’s PKN Buys Lithuania Refinery for \$2.6 Billion,” Reuters (26 May 2006).

28 Vladimir Kovalev, "Gazprom Secures Uzbekistan Gas through Politics and Pipelines,” FSU Oil \& Gas Monitor (23 January 2006).

29 Kerin Hope, "Russia to Discuss Gazprom Role in Aegean Pipeline,” FT.com (5 February 2006), at http://search.ft.com/search/quickSearch_Run.html (viewed 6 February 2006).

30 A large share of Russia’s natural gas exports to Western Europe pass through Ukraine and Belarus, which withdraw a certain amount of gas from the pipelines for their own use.

31 “Russia Turns up the Gas,” Guardian Weekly (23 December 2005-5 January 2006), 41; Peter Finn, "Russia Reverses Itself on Gas Cuts,” The Washington Post (3 January 2006), A12; Andrew E. Kramer, "Russia Restores Most of Gas Cut to Ukraine Line,” The New York Times (3 January 2006), at http://www.nytimes.com/2006/01/03/international/europe/ 03ukraine.html?pagewanted=print (viewed 3 January 2006). 
business for increased transit fees. ${ }^{32}$ One report stated that Gazprom wanted to gain at least some ownership of Ukraine's pipeline system. ${ }^{33}$

Later in January 2006, through no fault of Russia, the apparent reliability of its natural gas supplies suffered further when severely cold weather raised Russian demand for gas and cut exports below contracted volumes. After a few temporary gas price agreements, a deal was reached between Russia and Ukraine in October 2006 under which Ukraine pays a moderate price for gas in return for political and other favors. $^{34}$

In other actions, Russia cut off gas supplies to Moldova during a price dispute in early January 2006. The countries reached an interim agreement after Moldova had been without Russian gas for two weeks. ${ }^{35}$ In late 2006, Gazprom appeared to be preparing to cut off gas supplies to Belarus and Georgia unless they agreed to pay much higher prices in 2007. Reportedly, Georgia soon "agreed” to a doubling of Gazprom's prices. ${ }^{36}$ Belarus and Gazprom signed a five-year contract on 1 January 2007, which stipulates that Belarus will pay increasingly higher prices for gas (starting at more than twice the old price) and that Gazprom will purchase a 50 percent interest in Belarus' gas pipeline network. ${ }^{37}$ The next week, Russia shut off the flow of crude oil to and through Belarus following its announcement of an oil export tax and Belarus' dual action of imposing a customs duty on oil transiting Belarus to other export markets, and taking some of the oil flow as payment of the customs duty. ${ }^{38}$ Destination countries had adequate inventory to cope in the short run, but criticized Russia's failure to warn

32 Graeme Smith, "Russia, Ukraine Settle Gas Dispute," GlobeandMail.com (5 January 2006), at www.theglobeandmail.com/international, type "Russia" in search box; Peter Finn, "Russia and Ukraine Reach Deal on Gas, Ending Dispute," The Washington Post (5 January 2006), A12; Mark Smedley and Mitchell Ritchie, "Russia, Ukraine Settle Gas Pricing Dispute," Oil Daily (5 January 2006), 1.

Oil Daily (5 January 2006). For a fuller discussion and analysis of the Russia-Ukraine gas dispute, see Jim Nichol, Steven Woehrel, and Bernard A. Gelb, Russia's Cutoff of Natural Gas to Ukraine: Context and Implications, CRS Report RS22378 (Washington, D.C.: Congressional Research Service, 15 February 2006).

34 “Ukraine Secures Gas Supplies for Questionable Political Price,” FSU Oil \& Gas Monitor (1 November 2006), 7; Gas Monitor (5 July 2006).

35 Neil Buckley and Sarah Laitner, "Moldova Reaches Gas Deal with Gazprom,” FT.com (17 January 2006), at http://search.ft.com/search/quickSearch_Run.html (viewed February 2006).

36 Information Division, OAO Gazprom, Press Release, "Gazprom Seals Contracts to Supply Gas to Georgia in 2007,” 22 December 2006; “Georgia 'Agrees (to) Russia Gas Bill,” BBC News (22 December 2006), available at http://newsvote.bbc.co.uk/mpapps/pagetools/print/ news.bbc.co.uk/2/hi/business/6203721.stm (viewed 11 January 2007).

37 Alan Cullison, "Belarus Yields to Russia," The Wall Street Journal (2 January 2007), A4; "Belarus, Russian Firm Sign 5-Year Deal for Gas,” The Washington Post (2 January 2007), A10.

38 "Russian Oil Disruption Rattles European Commission, Germany," Oil Daily (9 January 2007), 2; Guy Chazen, Gregory L. White, and Marc Champion, "Russian Oil Cutoff Rouses Europe's Doubt,” The Wall Street Journal (9 January 2007), A3. 
them that a shut-off was possible. ${ }^{39}$ Oil began flowing again late on 10 January 2007, after Belarus lifted the transit duty, helping the countries reach a tentative agreement. ${ }^{40}$ The Moldova, Georgia, and Belarus incidents have heightened concern about Russia's reliability and encouraged investigations of non-Russian energy sources by several states of the former Soviet Union as well as Western Europe.

Russia initially opposed any Western investment in Caspian Sea energy projects, insisting that oil from the region be transported through Russian territory to Black Sea ports and arguing for equal sharing of Caspian Sea oil and gas. This attitude reflected the extensive energy ties between Russia and Central Asian countries, stemming from the numerous transportation routes from that area through Russia. But Russia has recently become more agreeable toward (and even cooperative with) Western energy projects, and it has signed an agreement with Azerbaijan and Kazakhstan on Caspian seabed borders, essentially based upon shore mileage.

In East Asia, China, Japan, and South Korea are trying to gain access to the largely undeveloped energy resources of Eastern Siberia as those countries strive to meet their increasing energy needs while reducing their dependence on the Middle East. China and Japan appear to be engaged in a bidding war over Russian projects, and are contesting access to Russian rival oil pipeline routes.

Many observers believe that Russia tried to use potential participation by U.S. firms in the development of the large Shtokmanovskoye gas field as leverage in its negotiations to gain entry into the World Trade Organization (WTO). ${ }^{41}$ Ultimately, Russia decided to rule out foreign equity participation in developing Shtokmanovskoye, but agreed to allow foreign companies to be involved as contractors and owners of the operating company. ${ }^{42}$ Another recent development-the July 2006 initial public offering (IPO) in which a portion of the state-owned oil company Rosneft was sold-has been seen by some as an attempt by Russia to attract investments by major foreign oil companies. Presumably, these firms hope that investing in the Rosneft IPO would gain them easier access to participation in Russian oil and gas projects. ${ }^{43}$

39 Gregory L. White and Guy Chazen, “Oil Spat Deepens Worry Over Russia’s Reliability.”

40 "Russia, Belarus End Druzhba Spat,” Oil Daily (11 January 2007), 1; Peter Finn, "RussiaBelarus Standoff Over Oil Ends, Clearing Way for Accord,” The Washington Post (11 January 2007).

41 Ed Reed, “Shtokmnanovskoye: the Wait Continues,” NewsBase CIS Oil \& Gas Special Report (July 2006); “G8 Adopts Energy Plan; Shtokman Slipping Away from U.S. Firms?” Oil Daily (18 July 2006); "Russian State Interference” and “Test Drilling on Shtokmanovskoye Begins,” FSU Oil \& Gas Monitor (26 July 2006).

42 “Shtokmanovskoye: Door Opens,” FSU Oil \& Gas Monitor (13 December 2006), 8; “Gazprom Rethinks Shtokmanovskoye Involvement,” FSU Oil \& Gas Monitor (11 April 2007), 6.

43 Steven Mufson, "Russian Oil Firm IPO Ends Early," The Washington Post (13 July 2006), D5; Gregory L. White and Alistair MacDonald, "Demand Allows Rosneft to Price IPO at High End,” The Wall Street Journal (14 July 2006), C1. Selling was stopped when only 1314 percent of the stock had been sold, yielding about USD 10.4 billion. Joanna Chung and Arkady Ostrovsky, "Rosneft IPO Fails to Attract Big Players,” Financial Times (15-16 July 2006), 9. 
Another instance of Russia's efforts to gain greater control over its energy resources is Gazprom's takeover of the majority interest in the Sakhalin Energy Investment Company (SEIC) on 21 December 2006, from Royal Dutch Shell. SEIC will remain the operator of the Sakhalin II project. ${ }^{44}$ The current SEIC partners will each dilute their stakes by half: Shell will retain a 27.5 percent stake, with Mitsui and Mitsubishi holding 12.5 percent and 10 percent stakes, respectively. In another Sakhalin development, the Russian government effectively rewrote the production-sharing agreement for Sakhalin-II, which now provides for a large annual dividend to Russia before the project's shareholders have recovered their capital expenditures (under the original agreement, capital expenditures were to be recovered before any dividends were paid). $^{45}$

Given foreign companies' technological capabilities and Russia's need for the most modern oil and gas extraction technology, a reported proposal to tighten restrictions on the extent to which foreign oil companies can participate in Russian oil and natural gas production and other ventures is potentially significant, and perhaps represents a move that is against Russia's own interests. Foreign companies (or Russian companies with at least 50 percent foreign participation) would not be allowed to develop fields with more than 513 million barrels of oil and 1.77 billion cubic feet of natural gas. ${ }^{46}$

\section{Major Proposed New or Expanded Pipelines ${ }^{47}$}

Because Russia's export facilities have limitations of both location and size, there are a number of proposals to build new terminals or to expand existing Russian oil and natural gas export pipelines and related facilities. Some proposals are contentious andwhile the Russian government perceives a need to expand its oil and gas export capacity—it has limited resources. Several selected proposals are discussed below.

\section{Druzhba Pipeline}

With a 1.2-1.4 million bbl/d capacity, the 2,500-mile Druzhba line is the largest of Russia’s oil pipelines to Europe. It begins in southern Russia, near Kazakhstan, where it collects oil from fields in the Urals and the Caspian Sea. In Belarus, it forks at Mozyr: one branch runs through Belarus, Poland, and Germany; and the other through Belarus, Ukraine, Slovakia, the Czech Republic, and Hungary (see Figure 2). Work has begun to increase capacity between Belarus and Poland. An extension to Wilhelms-

44 Sakhalin Energy, “Gazprom, Shell, Mitsui, Mitsubishi Sign Sakhalin II Protocol,” at www.sakhalinenergy.com/en/ (viewed 11 January 2007); Ed Reed, "Sakhalin Smash and Grab,” FSU Oil \& Gas Monitor (10 January 2007), 2.

45 “Moscow to Receive Sakhalin Dividends Ahead of Schedule,” FSU Oil \& Gas Monitor (2 May 2007), 11.

46 Arkady Ostrovsky, “Russia May Tighten Foreign Oil Groups’ Access to Reserves,” Financial Times (14 June 2006), 8.

47 Much of the discussion of Russian oil and gas pipelines is taken from the Russia Country Analysis Brief of February 2005 and April 2007, prepared by the Energy Information Administration. 


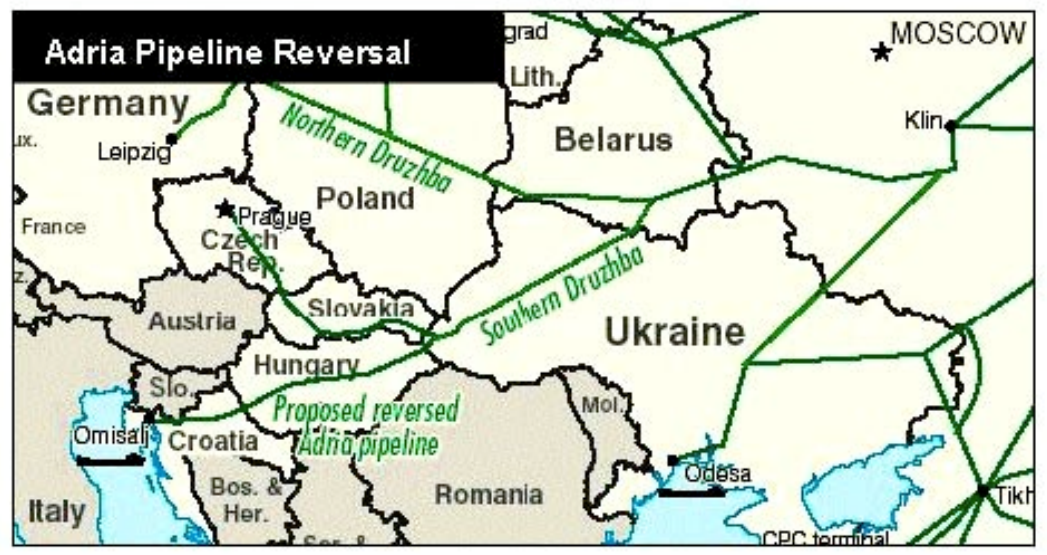

Figure 2: Druzhba and Adria Oil Pipelines ${ }^{48}$

haven, Germany would reduce Baltic Sea tanker traffic and allow Russia to export oil to the United States via Germany.

\section{Baltic Pipeline System}

The Baltic Pipeline System (BPS) carries crude oil from Russia's West Siberian and Tyumen-Pechora oil provinces westward to the newly completed port of Primorsk on the Russian Gulf of Finland (see Figure 3). Throughput capacity at Primorsk has been raised to around one million $\mathrm{bbl} / \mathrm{d}$, and, pending government approval, will be expanded to 1.2 million bbl/d. The BPS gives Russia a direct outlet to Northern European markets, reducing dependence on routes that run through the Baltic states. The rerouting of Russian crude through the BPS has come at a considerable cost to those countries. Russian authorities have stated that preference will be given to sea ports in which Russia has a stake over foreign ones. But the waterways through which tankers leaving from Primorsk and most other Russian export ports must transit limit tanker size, and therefore the price competitiveness of their cargoes.

\section{Additional Proposed Pipelines}

Some additional proposed lines would carry oil from Russia's West Siberian and Tyumen-Pechora basins west and north, going above the Baltic port at Primorsk to a deepwater terminal at Murmansk or Indiga on the Barents Sea (see Figure 3). This would enable 1.6-2.4 million bbl/d of Russian oil to reach the United States via tankers in only nine days, a much shorter transit time than from the Middle East or Africa. Liquefied natural gas facilities at Murmansk and Arkhangelsk have also been suggested, possibly allowing for gas exports to U.S. markets. The Indiga route would be

48 Map from Energy Information Administration, Russia Country Analysis Brief. 


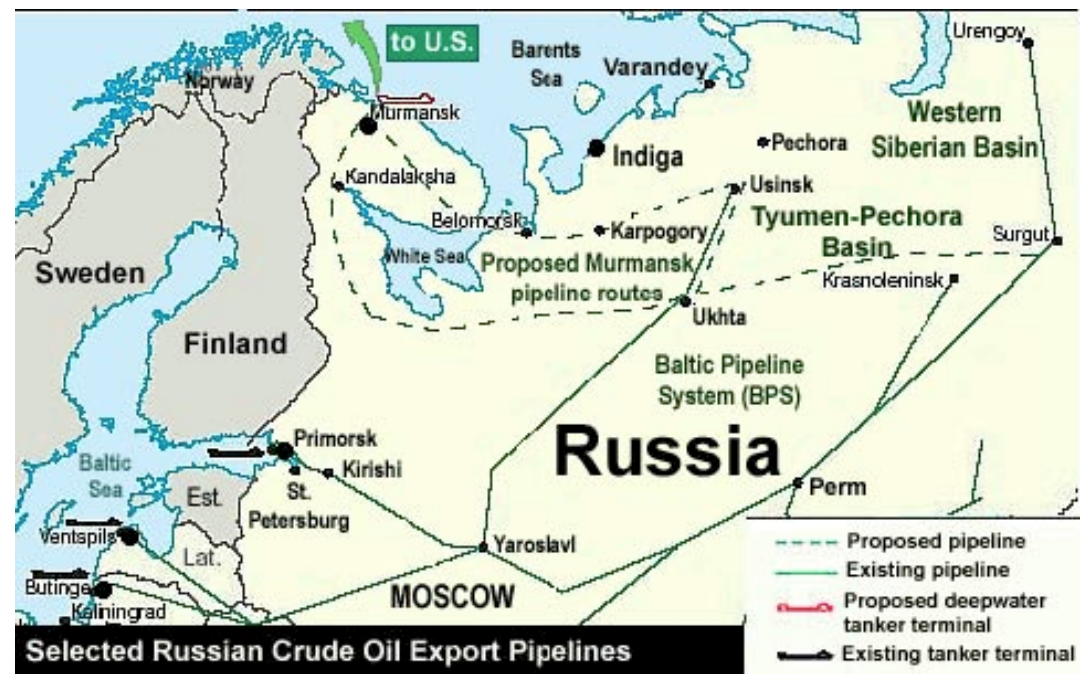

Figure 3: Selected Northwestern Oil Pipelines ${ }^{49}$

closer to the Tyumen-Pechora oil fields and shorter; Transneft's CEO has also said that the Murmansk project is not economically feasible. However, in contrast with Murmansk, the port of Indiga ices over during the winter, a disadvantage that may be reduced or eliminated if Arctic ice melting continues.

The Adria oil pipeline runs between Croatia's Adriatic Sea port of Omisalj and Hungary (see Figure 2). Originally designed to load Middle Eastern oil at Omisalj and pipe it northward to Yugoslavia and then to Hungary, the pipeline's operators and transit states have been considering reversing the flow-a relatively simple step-giving Russia a new export outlet on the Adriatic Sea. Connecting the pipeline to Russia's Southern Druzhba system requires the agreement of Russia, Belarus, Ukraine, Slovakia, Hungary, and Croatia. These countries signed a preliminary agreement on the project in December 2002; however, negotiations over the details (including tariffs and environmental issues) have been slow. Some analysts expect that the Adria pipeline could transport about 100,000 bbl/d of Russian crude oil in the first year of reversal, with an ultimate capacity of about $300,000 \mathrm{bbl} / \mathrm{d}$.

A trans-Balkan oil pipeline is being developed as an alternative to bringing oil originating in Southern Russia and the Caspian region to market through the Bosporus. As was discussed above, the passage of oil cargoes through the Turkish Straits can be disrupted due to weather or tanker and other cargo congestion. The trans-Balkan pipeline, with a capacity of 750,000 bbl/d, would circumvent this bottleneck. The pipeline would be supplied by oil delivered to the Black Sea through existing pipelines. The oil would then be shipped across the Black Sea by tanker from the Russian ports of Novo-

Ibid. 
rossiysk and Tuapse, or the Georgian ports of Supsa and Batumi, to the port of Bourgas in Bulgaria (see Figure 4). The oil would then enter the proposed 570-mile pipeline across Bulgaria, Macedonia, and Albania, and terminate at the port of Vlore on the Adriatic Sea, where it could be loaded on tankers for transit to the European and U.S. markets. The governments of all three Balkan nations involved in the proposed pipeline have approved the project, and AMBO LLC, the project developer and coordinator, is seeking financing for the project. Construction could begin in 2008, and the pipeline may become operational by 2011..$^{50}$

The increasingly large Chinese demand for oil has led to serious consideration of building a pipeline from the Russian city of Taishet (northwest of Angarsk) to Nakhodka (near the Sea of Japan) or to Daqing, China (see Figure 5). Both routes pass close to Lake Baikal, a site that presents environment-related obstacles. The Nakhodka route, which is longer, would provide a new Pacific port from which Russian oil could be shipped by tanker to Japan and other Asian markets and possibly to North America. Japan has offered USD 5 billion to finance construction and USD 2 billion for oil field

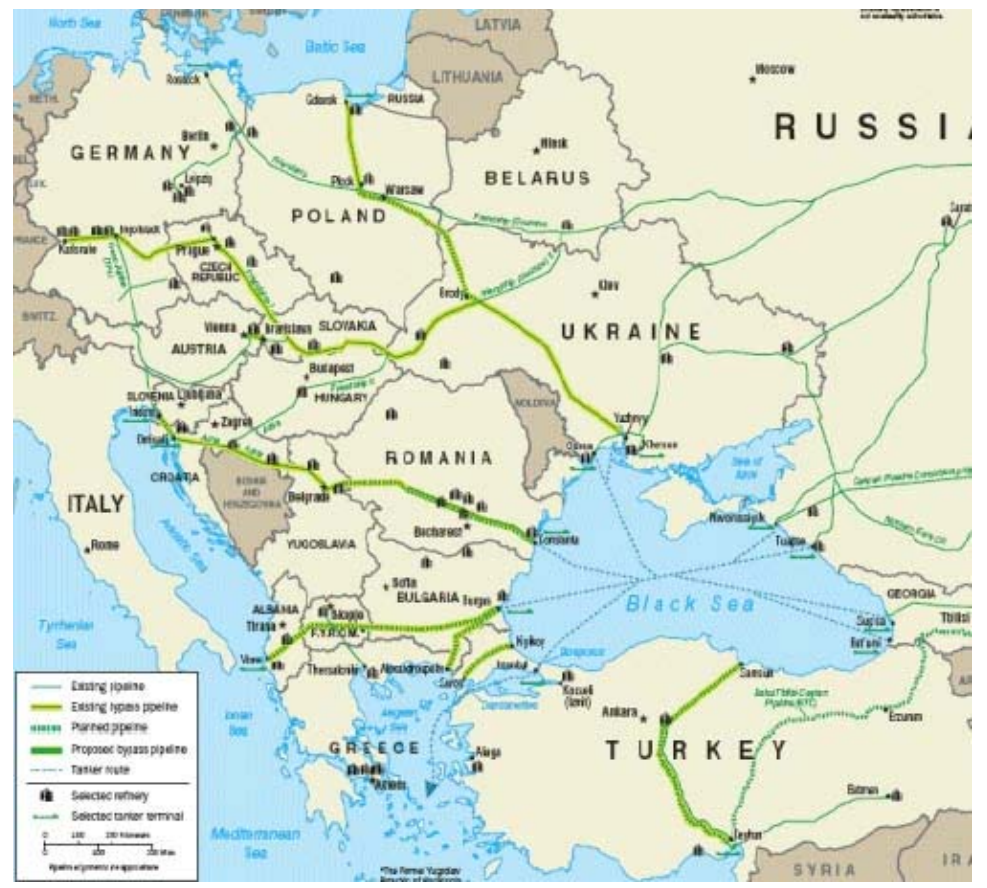

Figure 4: Proposed Bosporus Bypass Options ${ }^{51}$

50 Bulgaria Ratifies Trans-Balkan Pipeline, Boston Globe online (Boston.com World News) (31 May 2007); available at www.boston.com/news.

51 Map from Energy Information Administration, Russia Country Analysis Brief. 
development. $^{52}$ The Daqing option is favored by China, although China could also obtain Russian exports via the Nakhodka route. China has pledged to invest USD 12 billion in Russia's infrastructure and energy sector by $2020 .^{53}$ From Russia's point of view, the Nakhodka route would offer access to multiple markets, whereas a terminus at Daqing would give China greater control over the exported oil. However, Russia's environmental safety supervisory body rejected the shorter route because it would pass too close to Lake Baikal, a United Nations world heritage site. ${ }^{54}$

The 750-mile Blue Stream natural gas pipeline, which has a designed capacity of 565 billion cubic feet annually, connects the Russian pipeline system to Turkey. Natural gas began flowing through the pipeline-246 miles of which is underneath the Black Sea-in December 2002. In March 2003, Turkey halted deliveries, invoking a contract clause allowing either party to stop deliveries for six months. Turkish leaders reportedly were unhappy with the price structure. ${ }^{55}$ Other possible factors include Turkey's commitment to receive more gas than its near-term domestic consumption levels required and agreements to transship gas to other countries. An agreement was reached in November 2003, and the flow resumed in December 2003.

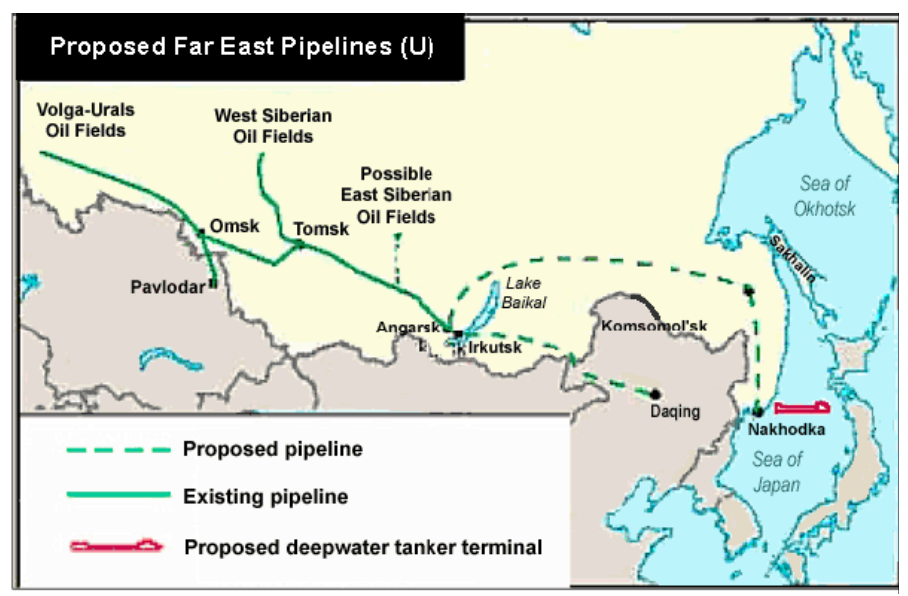

Figure 5: Proposed Far East Oil Pipelines ${ }^{56}$

52 Mark Katz, “Don’t Dismiss China’s Daqing Oil Pipeline,” Asia Times Online (1 October 2004).

53 Sergei Blagov, “China’s Russian Pipe Dream,” Asia Times Online (28 September 2004).

54 Eric Watkins, "Russia Nixes East Siberia Pipeline Route,” Oil \& Gas Journal Daily Update (6 February 2006), at http://ogj.pennet.com/articles/article_display.cfm?article_id= 247386 (viewed 7 February 2006).

55 Mevlut Katik, "Blue Stream's Pipeline's Future in Doubt Amid Russian Turkish Pricing Dispute,” Eurasianet.org (2 June 2003), available at www.eurasianet.org/departments/business/ articles/eav060203a_pr.shtml (viewed 18 December 2005).

56 Map from Energy Information Administration, Russia Country Analysis Brief. 
The Yamal-Europe I pipeline (unidentified northern route in Russia in Figure 6) carries one trillion cubic feet (tcf) of gas per year from Russia to Poland and Germany via Belarus. One proposal would expand it by another tcf per year with the addition of a second branch: Yamal-Europe II. However, Poland wants a route that runs entirely through its own territory and then to Germany (Yamal-Europe on the map), while Gazprom is seeking a route that runs via southeastern Poland and Slovakia (Yamal II).

A North Trans-Gas pipeline, or North European Gas Pipeline (NEGP), extending over two thousand miles from Russia through the Gulf of Finland to Denmark-and, ultimately, to the United Kingdom, via the Baltic and North Seas-was proposed in June 2003 by Russia and the United Kingdom. ${ }^{57}$ Gazprom and Germany's BASF and E.ON agreed on 8 September 2005 to set up a joint venture to build the pipeline. Originating in the St. Petersburg region, a 700-mile segment of the pipeline is to pass under the Baltic Sea. The first leg of the pipeline, which is under construction, is scheduled to come on stream in $2010 .^{58}$ This new pipeline route will benefit Russia, since it

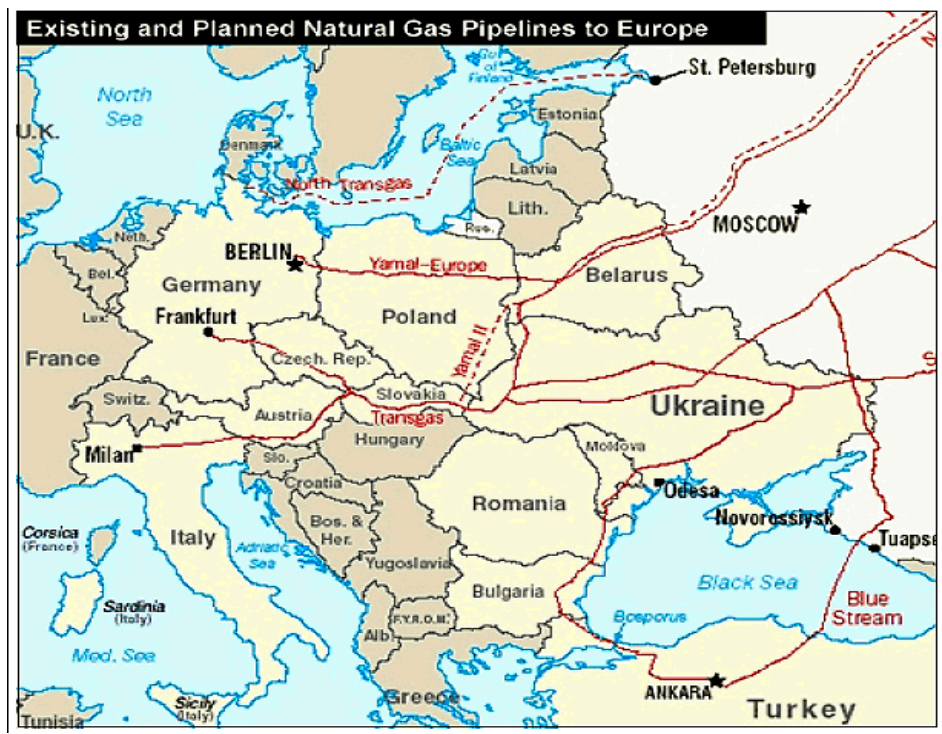

Figure 6: Natural Gas Pipelines to Europe ${ }^{59}$

57 Mark A. Smith, The Russian, German, and Polish Triangle, Russian Series 05/61 (Swindon: Conflict Studies Research Centre, U.K. Defence Academy, October 2005); available at www.defac.ac.uk/colleges/csrc/document-listings/russian/05(61)MAS.pdf.

58 "Factbox: North European Gas Pipeline," Ria Novosti (9 December 2005); available at http://en.rian.ru/russia/20051209/42408722.html (viewed 28 December 2005). BASF is mainly a chemical manufacturer, but has a subsidiary that explores for and produces oil and natural gas. E.ON is an electric power generator and distributor and a distributor of natural gas.

59 Map from Energy Information Administration, Russia Country Analysis Brief. 
will no longer have to negotiate transit fees with intermediary countries or pay them in natural gas. The pipeline agreement has been criticized by some European nations, who object to the fact that it was reached without consultation with them and who see the pipeline as an unfair circumvention of their territory born of political motivations and oblivious to the environmental risks. Perhaps to supplement or substitute for the NEGP, Gazprom is planning to build an LNG plant in the St. Petersburg area.

In a move that threatens to send substantial quantities of Central Asian natural gas through Russia to European markets, Russia announced in mid-May 2007 an agreement with Kazakhstan and Turkmenistan to build a pipeline feeding Central Asian natural gas into Russia's network of pipelines to Europe. The pipeline is to send mainly gas from Turkmenistan in a route along the Caspian Sea coast through Kazakhstan into Russia. $^{60}$

Rusia Petroleum-a consortium of TNK-BP, South Korea's state-owned Korea Gas Corporation, and the Chinese National Petroleum Company-has announced plans to construct a pipeline connecting Russia's Kovykta natural gas field (two trillion cubic meters of gas reserves) to China's northeastern provinces and across the Yellow Sea to South Korea. ${ }^{61}$ The plan calls for a pipeline that ultimately would have a capacity of forty billion cubic meters per year, delivering roughly half of its natural gas to China and the rest to South Korea and the domestic market en route. ${ }^{62}$

\section{Implications for the United States ${ }^{63}$}

Given that the United States-like Russia-is both a major energy producer and consumer, Russian energy trends and policies affect U.S. energy markets and U.S. economic welfare in general. Other things being equal, should Russia considerably increase its energy production and its ability to export that energy both westward and eastward, it may tend to ease the supply situation in energy markets in both the Atlantic and Pacific Basins. In the Atlantic arena, more Russian oil could be available to the United States. In the Pacific area, there would tend to be more supply available to countries trying to assure themselves of consistent energy supplies, such as China and Japan. This may ease the global competition for Persian Gulf oil.

On the other hand, the Russian government's moves to take control of the country's energy supplies discussed above may have the effect of making less oil available on the world market. This could occur if Russia's tendency to limit foreign firms' involve-

60 “Caspian Pipeline Deal Increases Russia’s Clout,” The Wall Street Journal (14 May 2007), A6.

61 TNK-BP, “Kovykta Project,” at http://www.tnk-bp.com/operations/exploration-production/ projects/kovykta (viewed 28 December 2005).

62 Selig S. Harrison, “Gas and Geopolitics in Northeast Asia,” World Policy Journal (Winter 2002/2003): 22-36.

63 For more discussion and analysis of U.S.-Russian economic relations, see William H. Cooper, Permanent Normal Trade Relations (PNTR) Status for Russia and U.S.-Russian Economic Ties, CRS Report RS21123 (Washington, D.C.: Congressional Research Service, updated 10 July 2007). 
ment in oil and gas development limits the introduction of the most modern technologies, or if Russia intentionally limits energy development and production.

Possibly as important as developments in the Russian oil and gas industry is the associated potential for U.S. suppliers of oil and gas field equipment and services to increase their sales in Russia. As noted above, the potential growth of both oil and natural gas production in Russia is limited by the lack of full deployment of the most modern Western oil and gas exploration, development, and production technologies. Although U.S.-Russian economic relations have expanded since the collapse of the Soviet Union, as successive Russian leaders have progressively dismantled the central economic planning system (including the liberalization of foreign trade and investment), the flow of trade and investment remains very low. U.S. suppliers of oil and gas field equipment had established a modest beachhead in Russia. However, whereas U.S. exports of oil and gas field machinery and equipment accounted for 14 percent of all U.S. goods exported to Russia in 2002, they accounted for only 7 percent in the first eleven months of 2006.

Similar to U.S. trade with Russia, U.S. investments there-especially direct investments - have increased since the dissolution of the Soviet Union, but the levels are far below their expected potential. Even so, as of 30 September 2006, the United States was Russia's third-largest source of foreign direct investment, with investments largely concentrated in the transportation, energy, communications, and engineering sectors. ${ }^{64}$

In this context, however, Russian economic policies and regulations have been a source of concern. The United States and the U.S. business community have asserted that structural problems and inefficient government regulations and policies in Russia have been a major cause of the low levels of trade and investment with the United States. While they consider the situation to be improving, potential investors complain that the climate for investment in Russia remains inhospitable. They point to burdensome tax laws; jurisdictional conflicts among Russian federal, regional, and local governments; inefficient and corrupt government bureaucracy; the absence of effective intellectual property rights protection; and the lack of a market-friendly commercial code as impediments to trade and foreign investment. And, more specifically, the forced breakup of Yukos has clouded prospects for private investment.

In addition, Russian energy trends and policies have possible implications for U.S. energy security. In its oversight role, the U.S. Congress may have an interest in Russia's significant role as a supplier to world energy markets in general, in Russia's role as a possible major exporter of energy to the United States, and in the changed patterns of world energy flows that could result from the completion of new Russian oil and natural gas export pipelines and related facilities or the expansion of existing export pipelines and related facilities.

Ibid. 


\section{THE QUARTERLY JOURNAL}

\section{Bibliography}

"AIOC: Oil Production Up, BTC Now Handling All Exports." FSU Oil \& Gas Monitor (2007).

"Belarus, Russian Firm Sign 5-Year Deal for Gas." The Washington Post (2007): A10.

"Caspian Pipeline Deal Increases Russia's Clout." The Wall Street Journal (2007): A6.

"Cold Spell Cuts Russian Gas to Europe(link is external)." Financial Times (2006).

"G8 Adopts Energy Plan; Shtokman Slipping Away from U.S. Firms?" Oil Daily (2006).

"Kazakhstan Inks BTC Deal." The Oil Daily (2006): 7.

"Kazakhstan, China Consider Gas Pipeline Construction." FSU Oil \& Gas Monitor (2005).

"Moscow to Receive Sakhalin Dividends Ahead of Schedule." FSU Oil \& Gas Monitor (2007): 11.

"New Takeover to Make Russia's Giant Gazprom one of the World's Largest Oil and Gas Companies." Pravda (2005).

"Putin: Private Oil Companies to Remain Private." FSU Oil \& Gas Monitor (2006).

"Russia Turns up the Gas." Guardian Weekly (2006): 41.

"Shtokmanovskoye: Door Opens." FSU Oil \& Gas Monitor (2006): 8.

"Ukraine Secures Gas Supplies for Questionable Political Price." FSU Oil \& Gas Monitor (2006): 7.

"Yukos: The Final Curtain." FSU Oil \& Gas Monitor (2006): 5.

Aris, Ben. "Death of Yukos." FSU Oil \& Gas Monitor (2006): 4.

Blagov, Sergei. "China’s Russian Pipe Dream." Asia Times Online (2004).

BP Statistical Review of World Energy(link is external)., 2009.

Buck, Tobias, and Neil Buckley. "Russian Parliament Vote Backs Gazprom Export Monopoly." Financial Times (2006): 8.

Buckley, Neil, and Sarah Laitner. Moldova Reaches Gas Deal with Gazprom(link is external). FT.com, 2006.

Bulgaria Ratifies Trans-Balkan Pipeline, Boston Globe(link is external). Boston.com World News, 2007. 
Chanlett-Avery, Emma. Rising Energy Competition and Energy Security in Northeast Asia: Issues for U.S. Policy In CRS Report. Washington, D.C.: Congressional Research Service, 2006.

Chazen, Guy, Gregory L. White, and Marc Champion. "Russian Oil Cutoff Rouses Europe's Doubt." The Wall Street Journal (2007): A3.

Chung, Joanna, and Arkady Ostrovsky. "Rosneft IPO Fails to Attract Big Players." Financial Times(2006): 9.

Clark, Martin. "Beijing Triumphs with Inauguration of Kazakhstani Crude Pipe." FSU Oil \& Gas Monitor (2005).

Cohen, Ariel. "Don’t Punish Latvia." Washington Times (2003).

Cooper, William H.. Permanent Normal Trade Relations (PNTR) Status for Russia and U.S.-Russian Economic Ties In CRS Report. Washington, D.C.: Congressional Research Service, 2007.

Country Analysis Briefs, Russia(link is external). Energy Information Administration (EIA), 2007.

Cullison, Alan. "Belarus Yields to Russia." The Wall Street Journal (2007): A4.

Factbox: North European Gas Pipeline(link is external). Ria Novosti, 2005.

Finn, Peter. "Russia and Ukraine Reach Deal on Gas, Ending Dispute." The Washington Post(2006): A12.

Finn, Peter. "Russia Reverses Itself on Gas Cuts." The Washington Post (2006): A12.

Finn, Peter. "Russia-Belarus Standoff Over Oil Ends, Clearing Way for Accord." The Washington Post (2007).

Gazprom Seals Contracts to Supply Gas to Georgia in 2007 In Press Release. Information Division, OAO Gazprom, 2006.

Gazprom, Shell, Mitsui, Mitsubishi Sign Sakhalin II Protocol(link is external). Sakhalin Energy, 2007.

Gelb, Bernard A.. Russian Natural Gas: Regional Dependence In CRS Report. Washington, D.C.: Congressional Research Service, 2007.

Georgia 'Agrees (to) Russia Gas Bill'(link is external). BBC News, 2006.

Goldman, Stuart D.. Russian Political, Economic, and Security Issues and U.S. Interests In CRS Report. Washington, D.C.: Congressional Research Service, 2007.

Harrison, Selig S.. "Gas and Geopolitics in Northeast Asia." World Policy Journal (2003): 22-36. 


\section{THE QUARTERLY JOURNAL}

Hope, Kerin. Russia to Discuss Gazprom Role in Aegean Pipeline(link is external). FT.com, 2006.

Katik, Mevlut. Blue Stream's Pipeline's Future in Doubt Amid Russian Turkish Pricing Dispute(link is external). Eurasianet.org, 2003.

Katz, Mark. "Don’t Dismiss China’s Daqing Oil Pipeline." Asia Times Online (2004).

Kovalev, Vladimir. "Gazprom Secures Uzbekistan Gas through Politics and Pipelines." FSU Oil \& Gas Monitor (2006).

Kovykta Project(link is external). TNK-BP, 2005.

Kramer, Andrew E.. "Russia Restores Most of Gas Cut to Ukraine Line(link is external)." The New York Times(2006).

Mufson, Steven. "Russian Oil Firm IPO Ends Early." The Washington Post (2006): D5.

Nichol, Jim, Steven Woehrel, and Bernard A. Gelb. Russia's Cutoff of Natural Gas to Ukraine: Context and Implications(link is external). Washington, D.C.: Congressional Research Service, 2006.

Ostrovsky, Arkady. "Russia May Tighten Foreign Oil Groups' Access to Reserves." Financial Times(2006): 8.

Reed, Ed. "Russian Gas Prices to Rise." FSU Oil \& Gas Monitor (2006): 2.

Reed, Ed. "Sakhalin Smash and Grab." FSU Oil \& Gas Monitor (2007): 2.

Reed, Ed. "Shtokmnanovskoye: the Wait Continues." NewsBase CIS Oil \& Gas Special Report(2006).

Romero, Simon, and Erin E. Arvedlund. "U.S. Court to Hear Arguments for Dismissal of Yukos Case." New York Times (2005).

Russia Country Analysis Brief(link is external). Energy Information Administration, 2005.

Schleifer, Yigal. "Russian Oil Ships Stuck in Bosporus Strait Traffic Jam." Christian Science Monitor(2005).

Smedley, Mark, and Mitchell Ritchie. "Russia, Ukraine Settle Gas Pricing Dispute." Oil Daily(2006): 1.

Smith, Mark A.. The Russian, German, and Polish Triangle(link is external) In Russian Series. Swindon: Conflict Studies Research Centre, U.K. Defence Academy, 2005. 
Spilimbergo, Antonio. Measuring the Performance of Fiscal Policy in Russia In IMF Working Paper. Washington, D.C.: International Monetary Fund, 2005.

Watkins, Eric. "Russia Nixes East Siberia Pipeline Route." Oil \& Gas Journal Daily Update (2006).

White, Gregory L., and Alistair MacDonald. "Demand Allows Rosneft to Price IPO at High End."The Wall Street Journal (2006). 